\title{
Profile of volatile organic compounds in musts and cachaças produced by selected
}

\section{Saccharomyces cerevisiae yeast strains}

\author{
Perfill de compostos orgânicos voláteis em mostos e cachaças produzidos por linhagens selecionadas
}

\author{
da levedura Saccharomyces cerevisiae
}

Perfil de compuestos orgánicos volátiles en mostos y cachaças producidos por cepas seleccionadas de la levadura Saccharomyces cerevisiae

Received: 03/17/2021 | Reviewed: 03/24/2021 | Accept: 03/28/2021 | Published: 04/09/2021

\author{
Amanda Lemes Silveira \\ ORCID: https://orcid.org/0000-0002-4678-861X \\ Centro Federal de Educação Tecnológica de Minas Gerais, Brazil \\ E-mail: amandalsilveira@gmail.com \\ Ana Maria de Resende Machado \\ ORCID: https://orcid.org/0000-0002-1587-5024 \\ Centro Federal de Educação Tecnológica de Minas Gerais, Brazil \\ E-mail: anamariaderesendemachado@gmail.com \\ Fátima de Cássia Oliveira Gomes \\ ORCID: https://orcid.org/0000-0001-7358-7154 \\ Centro Federal de Educação Tecnológica de Minas Gerais, Brazil \\ E-mail: fatimaog@cefetmg.br \\ Cleverson Fernando Garcia \\ ORCID: https://orcid.org/0000-0001-9354-1401 \\ Centro Federal de Educação Tecnológica de Minas Gerais, Brazil \\ E-mail: cf.garcia@ terra.com.br \\ Fernanda Badotti \\ ORCID: https://orcid.org/0000-0001-9038-4631 \\ Centro Federal de Educação Tecnológica de Minas Gerais, Brazil \\ E-mail: fbadotti@ cefetmg.br
}

\begin{abstract}
Alembic cachaça is a beverage of great cultural and economic importance in Brazil. However, its quality is variable and difficult to control, mainly because the fermentation process occurs in open vats and is conducted by many different microorganisms which produce a great variability of chemical compounds. The use of selected yeast strains as starters has been considered an excellent alternative to the traditionally used spontaneous fermentation, since it allows the production of cachaças less subject to variation and in general, of higher quality. Still, the use of yeast strains isolated from producing areas (autóctones) would contribute for the production of beverages which carry the identity of the geographic region. In this study, we evaluated the volatile fraction of organic compounds in musts and cachaças produced by three autóctones Saccharomyces cerevisiae yeast strains. Our aim was to correlate the chemical profile of the samples with the strains to evaluate the viability of using such starters for large-scale cachaça production. More than 200 compounds belonging to seven different chemical groups were identified using solid-phase microextraction coupled to gas chromatography-mass spectrometry. The number of compounds identified in the cachaças was superior to those found in musts and those that most influenced for the differentiation of the samples were acetic and octanoic acid for musts, and ethyl decanoate and ethyl dodecanoate esters for cachaças. Multivariate analysis showed that the distillation process, as well as the fermentation microenvironment had the greatest influence on the chemical composition.
\end{abstract}

Keywords: Alembic cachaças; Autóctones strains; Chemical composition.

\section{Resumo}

A cachaça de alambique é uma bebida de grande importância cultural e econômica no Brasil. Porém, sua qualidade é variável e de difícil controle, principalmente porque o processo de fermentação ocorre em dornas abertas, sendo conduzido por diversos microrganismos que produzem uma grande variabilidade de compostos químicos. O uso de leveduras selecionadas tem sido considerado uma excelente alternativa à fermentação espontânea tradicional, pois permite a produção de cachaças menos sujeitas a variações e, em geral, de maior qualidade. Ainda, o uso de leveduras isoladas de áreas produtoras (autóctones) contribuiria para a produção de bebidas que carregam a identidade da região geográfica. Neste estudo, avaliou-se a fração volátil de compostos orgânicos em mostos e cachaças produzidos por três linhagens autóctones de leveduras Saccharomyces cerevisiae. Nosso objetivo foi correlacionar o perfil químico das amostras com as leveduras para avaliar a viabilidade do uso de tais iniciadoras para a produção de cachaça em larga escala. Mais de 200 compostos pertencentes a sete diferentes grupos químicos foram identificados usando 
microextração em fase sólida acoplada a cromatografia gasosa-espectrometria de massas. O número de compostos identificados nas cachaças foi superior aos encontrados nos mostos, e os que mais influenciaram na diferenciação das amostras foram os ácidos acético e octanóico para os mostos, e os ésteres etil decanoato e etil dodecanoato para as cachaças. A análise multivariada mostrou que o processo de destilação, assim como o microambiente fermentativo tiveram maior influência na composição química.

Palavras-chave: Cachaça de Alambique; Linhagens autóctones; Composição química.

\section{Resumen}

La cachaça de alambique es una bebida de gran importancia cultural y económica en Brasil. Sin embargo, su calidad es variable y difícil de controlar, principalmente porque el proceso de fermentación ocurre en tinas abiertas, siendo realizado por varios microorganismos que producen una gran variabilidad de compuestos químicos. El uso de levaduras seleccionadas se ha considerado una excelente alternativa a la fermentación espontánea tradicional, ya que permite la elaboración de cachaças menos sujetas a variaciones y, en general, de mayor calidad. Además, el uso de levaduras aisladas de áreas productoras nativas contribuiría a la producción de bebidas que llevan la identidad de la región geográfica. En este estudio se evaluó la fracción volátil de compuestos orgánicos en mostos y cachaças producidos por tres levaduras nativas de la especie Saccharomyces cerevisiae. Nuestro objetivo fue correlacionar el perfil químico de las muestras con las levaduras para evaluar la viabilidad de utilizar dichos iniciadores para la producción de cachaça a gran escala. Se identificaron más de 200 compuestos pertenecientes a siete grupos químicos diferentes mediante microextracción en fase sólida junto con cromatografía de gases-espectrometría de masas. El número de compuestos identificados en las cachaças fue superior a los encontrados en los mostos, y los que más influyeron en la diferenciación de las muestras fueron los ácidos acético y octanoico para los mostos, y los ésteres de decanoato de etilo y dodecanoato de etilo para las cachaças. El análisis multivariado mostró que el proceso de destilación, así como el microambiente fermentativo, tuvieron una mayor influencia en la composición química.

Palabras clave: Cachaça de Alambique; Cepas nativas; Composición química.

\section{Introduction}

Alembic cachaça is one of the most traditional and widely consumed beverages in Brazil, and its quality has been increasingly recognized worldwide. According to the Brazilian Ministry of Agriculture, 8.41 million litres of cachaça were exported to 77 countries in 2018, a volume which represented a profit of US\$ 15.61 million. Despite the expressive numbers, only about $1 \%$ of the beverage produced is exported. Therefore, it is evident that the economic and cultural potentials of cachaça are still little explored, and one of the main barriers to that is the lack of assurance in the continued supply of a highquality product.

Fermentation is considered to be one of the determining steps for producing good quality cachaça. During this process, a complex microbial community, composed mainly of the yeast Saccharomyces cerevisiae, performs chemical reactions that lead to the formation of different products. Spontaneous fermentation is the system of choice for the production of alembic cachaça and consists of using the microbiota that naturally inhabit sugarcane juice and distillery equipment (Badotti et al., 2012). This natural starter is usually prepared by leaving sugarcane juice with corn, soybean, or rice flour exposed to the air until the microbiota reaches a suitable cell concentration to initiate a fermentation cycle. This inoculum preparation method is popularly known as fermento caipira, and there is no standardization for its production (Gomes et al., 2007; Faria-Oliveira et al., 2015).

Many studies have focused on isolating strains of S. cerevisiae from spontaneous fermentations to evaluate their potential as starters for large-scale cachaça production (Gomes et al., 2007; Badotti et al., 2010; Barbosa et al., 2016; Paredes et al., 2018; D'Silva et al., 2019). The use of wild strains preserves the characteristics of a specific geographic region, and it allows the association of the product with the place where it was produced. The use of selected strains to conduct the fermentation processes are also related to the prevention of off-flavours, fast-start fermentation cycles, and lower chemical variations in the product (Badotti et al., 2012; Barbosa et al., 2016; Portugal et al., 2016).

The flavour of cachaça is mainly determined by the compounds that comprise its complex volatile fraction. According to Brazilian legislation, the volatile components of cachaça are established as the sum of volatile acids, total esters, aldehydes, furfural and higher alcohols. However, the individual contribution of each of these components to the beverage quality is 
difficult to determine. In addition to the importance for the flavor, the identification of volatile compounds is imperative for consumer protection, as it can prevent fraud. The chemical profile of different brands of cachaça and other Brazilian distillates have been used to identify the presence of toxic compounds (Bortoletto \& Alcarde, 2015), as well as for the chemical traceability of cachaças produced by different fermentation and distillation systems (Serafim \& Franco, 2015).

Solid phase microextraction (SPME) has been widely applied in analytical practices, because of its operational simplicity, short extraction time, does not require organic solvents, and ability to analyse volatile compounds from matrices of different compositions. SPME also offers the possibility of automation as a result of the straightforward combination with gas chromatography (GC) (Charry-Parra et al., 2011; Silva \& Pawliszyn, 2012). The technique can be performed by the direct immersion of the sample (DI-SPME) or by headspace extraction (HS-SPME). HS-SPME has been successfully used for the isolation, pre-concentration and determination of compounds detected in the volatile fractions of alcoholic beverages (De Souza et al., 2009; Khio et al., 2012; Pérez-González et al., 2015; Ruiz-Delagado et al., 2016).

In this study, the volatile organic compounds present in musts and cachaças produced by three S. cerevisiae strains were extracted using HS-SPME and identified using gas chromatography associated with mass spectrometry (GC-MS). The purpose of this work was to characterize the chemical profile of the samples and evaluate the potential of the yeast strains to be used as starters for the alembic cachaça large-scale production.

\section{Materials and Methods}

\subsection{Methodology}

Three selected yeasts strains were used in the fermentations, in two distilleries, for the production of cachaça. In each distillery spontaneous fermentation were conducted as a control (Gomes et al. 2007).

Volatile compounds were identified by comparison of their spectra with the NIST 2005 library. The identity was confirmed by comparison with the Kovats indices reported in the literature (Adams, 2007).

Volatile compounds from cachaças and musts obtained from spontaneous fermentation and from selected yeasts strains were analyzed using GC-MS after extraction by SPME (De Souza et al., 2009). The data were analyzed using Principal Component Analysis (PCA).

\subsection{Experiments and sample collection in the distilleries}

Three S. cerevisiae yeast strains (denominated SS1, SS2 and SS3) previously isolated from spontaneous fermentations for cachaça production were selected for use in this study. The three were chosen from dozens of strains evaluated taking into account characteristics such as high ethanol production, resistance to the stress conditions imposed by the fermentation process (Badotti et al., 2010) and production of low levels of acetyl carbamate (Borges et al., 2014).

The experiments were performed in two distilleries (A and B) of the state of Minas Gerais, Brazil. Distilleries A and B were $10 \mathrm{Km}$ distant from each other, and the experiments were performed in the producing seasons of 2011 and 2012. Fermentations conducted using the strains SS1 and SS2, as well as the control spontaneous fermentation SF1, were performed in distillery A. Fermentations conducted by the strain SS3 and the spontaneous fermentation SF2 were performed in distillery B. The experiments were performed in nearby distilleries, with similar climatic conditions and using standard protocol (Gomes et al. (2007). The starter S. cerevisiae strains were grown on modified Sabouraud agar (glucose $2 \%$, peptone $1 \%$, yeast extract $0.5 \%$ and agar $2 \%$ ) at room temperature for $24 \mathrm{~h}$, from which $1 \mathrm{~mL}$ of a suspension containing about $1 \times 10^{7}$ cells was used to inoculate flasks containing $100 \mathrm{~mL}$ of SCY broth (sugarcane juice $50 \%$, glucose $0.5 \%$, yeast extract $0.5 \%$ and distilled water $50 \%$ ). The flasks were incubated at $25 \pm 1{ }^{\circ} \mathrm{C}$ for $24 \mathrm{~h}$. The pre-inoculum was then transferred to flasks with $5 \mathrm{~L}$ of SCY broth, and incubated at room temperature $\left(25 \pm 3{ }^{\circ} \mathrm{C}\right)$ for $24 \mathrm{~h}$. Ten liters of this second pre-inoculum was added to the vats. The 
fermentations were conducted in steel vats of $1500 \mathrm{~L}$ of capacity. The pre-inoculum was mixed with $90 \mathrm{~L}$ of sugarcane juice at $8^{\circ}$ Brix. After $24 \mathrm{~h}$, a volume of $200 \mathrm{~L}$ of sugarcane juice at $10^{\circ}$ Brix was added to the fermentation vat. On the third day, 300 $\mathrm{L}$ sugarcane juice at $12^{\circ}$ Brix were added. On the fourth day, $400 \mathrm{~L}$ sugarcane juice at $20^{\circ}$ Brix were added to the vat containing the selected yeast strain, to a final volume of $1000 \mathrm{~L}$. After $24 \mathrm{~h}$, the vine produced was distilled, and a new fermentative cycle began, using the same starter. At the same time, one traditional batch (natural ferment) was made by spontaneous fermentation by the distillery owner. One of the main peculiarity of the artisanal production of cachaça is the preparation of the starter ferment, which consists of the propagation of the fermentative microbiota through a mix of sugar cane juice with corn, rice and/or soya flour. The process occurs inside the fermentation vat and can last from 5 to 20 days, until the yeast population is sufficient to initiate the fermentative cycle. The fermentative cycle results in the consumption of the total sugar present in the sugar cane juice and occurs in a period that can vary between 18 to 48 hours. The whole experiment was carried out so as to make all the vats reach maximum capacity $(1000 \mathrm{~L})$ on the same day, and the same sugarcane juice lot was used in each fermentation and distillation process.

Each fermentation cycle for alembic cachaça production lasts about $24 \mathrm{~h}$, and the inoculum is reused for approximately 25 cycles. Samples of must and cachaça were collected from vats during fermentation cycles 7, 14 and 21 as representatives of the beginning, middle and end of the inoculum life cycle. Must samples were collected from the vats using sterile 500-mL flasks, taken to the laboratory in an ice bath and processed within $24 \mathrm{~h}$. Samples were centrifuged at $1663 \mathrm{~g}$ and filtered through a $0.45-\mu \mathrm{m}$ membrane (Millipore, USA) for further analyses. The distillation of musts was performed in copper alembics. Cachaça distillation carried out in alembic stills produces different fractions, which are classified into 'head', which corresponds to 8 to $10 \%$ of the total volume of still wine; 'heart', which corresponds to $80 \%$ of the volume and 'tail', which corresponds to 8 to $10 \%$ of the total wine volume. The main requirement for a good quality cachaça is to know the exact separation of the heart phase from the other two fractions. Samples of freshly distilled cachaça were stored in glass bottles for further analyses.

\subsection{Solid phase microextraction by headspace extraction}

For SPME analyses, an aliquot of $1 \mathrm{~mL}$ of each sample was placed in a $20-\mathrm{mL}$ glass vial containing $9 \mathrm{~mL}$ of deionized water and $0.5 \mathrm{~g} \mathrm{NaCl}$. The solution was hermetically closed with a Teflon septum and aluminium cap. The sample was heated at $60{ }^{\circ} \mathrm{C}$ with magnetic stirring for $10 \mathrm{~min}$, and the volatile fraction was collected in the headspace using an 85 - $\mu \mathrm{m}$ polyacrylate (PA) SPME fibre inserted into a manual holder (Supelco, Bellefonte, PA, USA). The fibre was exposed for 25 min and then manually introduced into the GC injector for thermal desorption for $10 \mathrm{~min}$ at $240{ }^{\circ} \mathrm{C}$ (De Souza et al., 2009).

\subsection{Gas Chromatography coupled with Mass Spectrometry}

Samples were analysed by gas chromatography (Agilent Technologies 7890A GC System) coupled with mass spectrometry (Agilent 5975C inert MSD Triple-Axis Detector). The HP5-MS column was $30 \mathrm{~m}$ in length, $0.25 \mathrm{~mm}$ I.D. and $0.25 \mu \mathrm{m}$ film thickness. The oven temperature program initiated at $35^{\circ} \mathrm{C}$ for 5 minutes and increased at a gradient of $3{ }^{\circ} \mathrm{C}$ min

${ }^{1}$ to $240{ }^{\circ} \mathrm{C}$, remaining at this temperature for 1 minute. The injection mode was splitless. Helium was used as the carrier gas at a flow rate of $1.3 \mathrm{~mL} \mathrm{~min}^{-1}$. The transfer line temperature was $250{ }^{\circ} \mathrm{C}$. A series of alkanes $(\mathrm{C} 8-\mathrm{C} 22)$ were evaluated using the same protocol to establish the retention indices and identify the compounds by comparison with the literature (De Souza et al., 2009). 


\subsection{Data analysis}

Volatile compounds were identified by comparison of their spectra with the NIST 2005 library. The identity was confirmed by comparison with the Kovats indices reported in the literature (Adams, 2007). The relative percentage of the compounds was calculated on the basis of the total peak area (the sum of individual peak areas) of the GC-MS chromatograms. The final value for each compound was calculated from the average of the triplicates (samples collected in the beginning, middle and end of fermentative cycles).

\subsection{Multivariate analysis}

Principal Components Analysis (PCA) and Hierarchical Cluster Analysis (HCA) were performed to group the samples according to their volatile constituents in the multivariate space. The relative areas of the volatile compounds were used to build the covariance matrix and the loading plot. The results of the matrix made it possible to generate a graph in which each axis represents a set of defined PCs. To perform the analysis, high values for relative areas (>5\%) and PCA score plots were obtained from the chemical compounds identified in the must and the cachaça samples (MINITAB INC. 2017).

Dendrograms were obtained using non-standard variables with Euclidean distance measurements and linkage methods (average, complete, Ward and McQuitty). The analyses were performed using the Minitab 18.1 software (Minitab Inc., State College, PA, USA).

\section{Results}

A total of 204 different volatile compounds were identified: 108 in musts and 168 in cachaças. Alcohols were prevalent in both relative amount and number of compounds: 58 in total, of which 31 were found in musts and 50 in cachaças. Ethanol, followed by the higher alcohols 3-methylbutanol (isoamyl alcohol), 2-phenylethyl alcohol and 2-methylpropanol (isobutyl alcohol) was detected in high concentrations in all the samples evaluated. Esters was the second most representative chemical group in the samples: 53 different compounds were identified, 39 in musts and 44 in cachaças. Ethyl octanoate and ethyl decanoate were the esters found in the largest relative amount in the samples. Moreover, ethyl acetate was present in all the cachaça samples analysed in this study (Table 1).

Forty-two hydrocarbons were identified, 14 in musts and 38 in cachaças. The hydrocarbons 4-vinylanisole, naphthalene, ionene and 4-vinylveratrole were detected in all the cachaças evaluated, including both spontaneous and selected strains. The presence of these compounds in the must samples was variable, and only the 4-vinylveratrole was detected in all the samples.

The aldehydes nonanal and decanal were detected in all the samples evaluated in this study, whereas trans-2-nonenal and pentadecanal were exclusively found in cachaças, and hexanal and 2-octenal were only found in musts. Fifteen aldehydes were identified in the samples, eight in musts and nine in cachaças. Thirteen ketones were identified in the samples; all of them were present in the cachaças, whereas only three were found in musts (Table 1).

Finally, nine carboxylic acids were identified in the samples, six in musts and five in cachaças. Acetic acid was the acid component detected in the highest concentration, and it was only found in musts, whereas octanoic and dodecanoic acids were present in both musts and cachaças. The cachaça samples evaluated in this study had a very low relative quantity of acids. Seven different acetals were identified in our samples, all of them in cachaças and only one, 1-(2-ethoxyethoxyethanol), in must (Table 1).

The grouping pattern generated from Principal Components Analysis (PCA) and Hierarchical Cluster Analysis (HCA) indicated different chemical compositions for musts and cachaças. The two principal components (PC1 and PC2) accounted for $91 \%$ of the total variance and provided discriminatory information for the samples (Figure 1). 
Research, Society and Development, v. 10, n. 4, e23410414009, 2021

(CC BY 4.0) | ISSN 2525-3409 | DOI: http://dx.doi.org/10.33448/rsd-v10i4.14009

Figure 1. PCA score plot obtained from the chemical compounds identified in the must and cachaça samples.

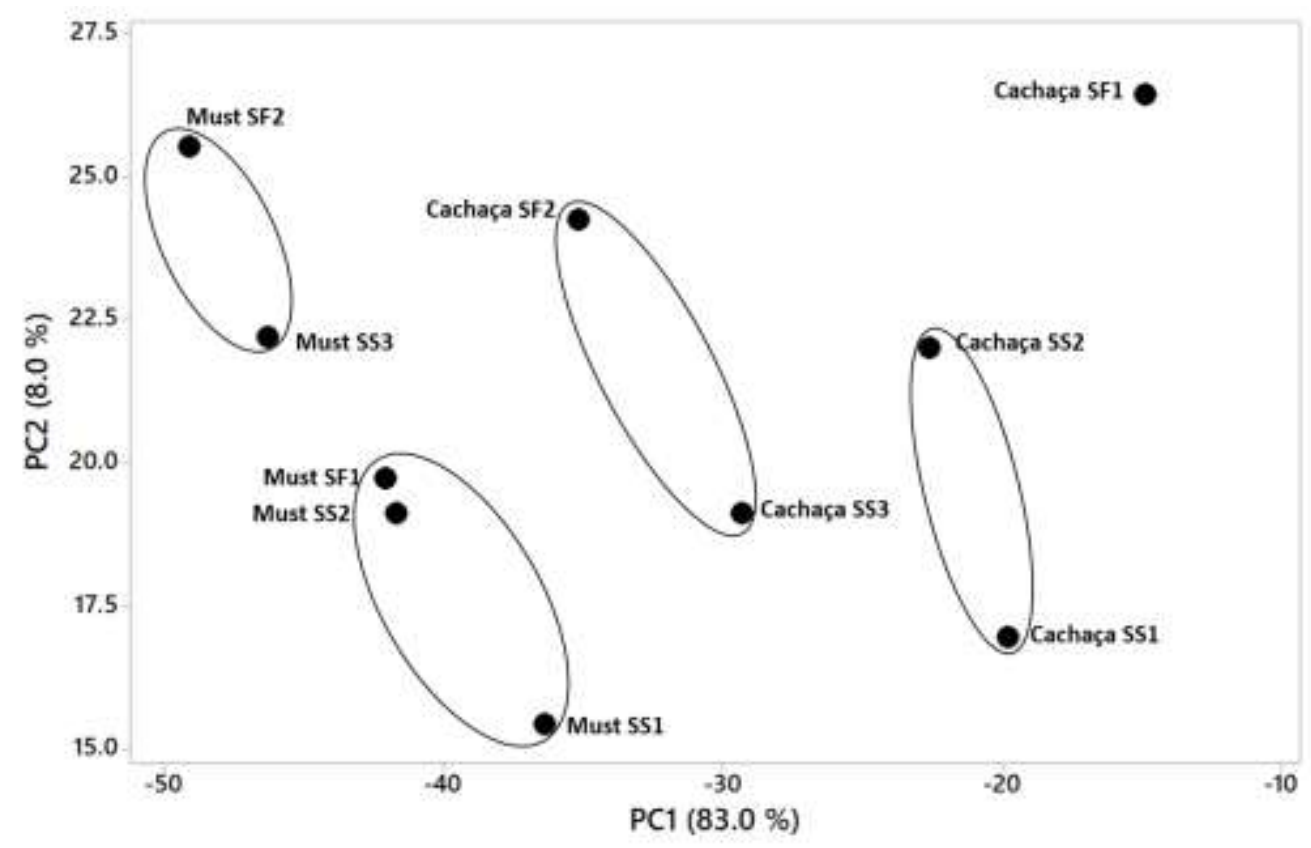

Source: Authors. 
Research, Society and Development, v. 10, n. 4, e23410414009, 2021

(CC BY 4.0) | ISSN 2525-3409 | DOI: http://dx.doi.org/10.33448/rsd-v10i4.14009

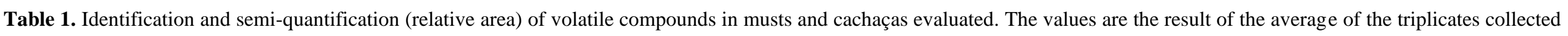
in the beginning, middle and end of fermentative cycles. See Material and Methods section for details.

\begin{tabular}{|c|c|c|c|c|c|c|c|c|c|c|}
\hline Compounds & $\begin{array}{c}\text { Must } \\
\text { SS1 } \\
\end{array}$ & $\begin{array}{c}\text { Must } \\
\text { SS2 } \\
\end{array}$ & $\begin{array}{c}\text { Must } \\
\text { SS3 } \\
\end{array}$ & $\begin{array}{c}\text { Must } \\
\text { SF1 } \\
\end{array}$ & $\begin{array}{c}\text { Must } \\
\text { SF2 }\end{array}$ & $\begin{array}{c}\text { Cachaça } \\
\text { SS1 } \\
\end{array}$ & $\begin{array}{c}\text { Cachaça } \\
\text { SS2 } \\
\end{array}$ & $\begin{array}{c}\text { Cachaça } \\
\text { SS3 } \\
\end{array}$ & $\begin{array}{c}\text { Cachaça } \\
\text { SF1 }\end{array}$ & $\begin{array}{c}\text { Cachaça } \\
\text { SF2 }\end{array}$ \\
\hline \multicolumn{11}{|l|}{ ACETAL/HEMICETAL } \\
\hline 1,1-diethoxybutane & - & - & - & - & - & 0.026 & - & & - & - \\
\hline 1,1-diethoxy-3-methylbutane & - & - & - & - & - & 0.030 & - & 0.033 & - & - \\
\hline 1,1-diethoxy-2-methylbutane & - & - & - & - & - & - & - & - & 0.023 & - \\
\hline 1,1-diethoxy-pentane & - & - & - & - & - & 0.045 & - & - & - & - \\
\hline 1-(2-ethoxyethoxyetanol) & 0.027 & 0.086 & - & - & - & 0.021 & - & 0.134 & 0.065 & 0.162 \\
\hline 1,3,3-triethoxypropane & - & - & - & - & - & - & 0.025 & - & - & 0.034 \\
\hline 1,1-diethoxyhexane & - & - & - & - & - & 0.019 & 0.009 & 0.028 & 0.014 & 0.029 \\
\hline \multicolumn{11}{|l|}{ CARBOXYLIC ACID } \\
\hline acetic acid & - & - & 6.168 & - & 2.733 & - & - & - & - & - \\
\hline hexanoic acid & - & - & 0.108 & - & - & - & - & - & - & - \\
\hline octanoic acid & - & 0.080 & 0.779 & 0.058 & 0.243 & - & - & 0.127 & 0.105 & - \\
\hline 3-phenyl 2-propenoic acid & - & - & - & - & - & - & - & 0.097 & - & - \\
\hline 10-undecynoic acid & - & - & - & - & - & - & - & 0.017 & - & - \\
\hline 5-cis-dodecenoic acid & - & - & - & - & - & 0.092 & 0.020 & 0.064 & 0.043 & 0.043 \\
\hline decanoic acid & - & 0.098 & - & - & - & - & - & - & - & - \\
\hline dodecanoic acid & - & 0.013 & - & - & - & - & - & 0.021 & 0.037 & 0.015 \\
\hline E-9-tetradecenoic acid & - & - & - & - & 0.043 & - & - & - & - & - \\
\hline \multicolumn{11}{|l|}{ ALCOHOL } \\
\hline etanol & 43.666 & 50.892 & 54.638 & 51.134 & 58.957 & 30.381 & 36.130 & 40.053 & 31.924 & 47.086 \\
\hline 2-methylpropanol & 2.28 & 2.723 & 3.557 & 1.946 & 3.941 & 1.892 & 2.343 & 1.844 & 1.823 & 2.600 \\
\hline 3-methyl-1-butanol & 14.324 & 11.187 & 13.480 & 14.098 & 12.388 & 14.218 & 13.157 & 14.984 & 13.077 & 12.814 \\
\hline 1-pentanol & - & - & 0.078 & - & 0.067 & 0.098 & - & 0.095 & - & 0.067 \\
\hline 2-methylbutanol & - & - & - & - & - & - & - & 0.036 & 0.026 & 0.031 \\
\hline 1,3-butanediol & - & 0.021 & - & - & - & - & - & - & - & - \\
\hline butane-2,3-diol & 1.754 & 1.658 & 1.393 & 1.735 & 1.374 & - & - & - & - & 0.180 \\
\hline 3-methyl-3-hexanol & - & - & 0.954 & - & - & - & - & 0.196 & - & - \\
\hline 1-hexanol & - & - & - & - & - & - & - & 0.029 & - & - \\
\hline 3-methyl-2-hexanol & - & - & 1.427 & - & - & - & - & 0.237 & - & - \\
\hline 2-heptanol & 0.048 & 0.070 & - & 0.057 & - & 0.037 & 0.067 & 0.054 & 0.047 & 0.064 \\
\hline 1-heptanol & 0.064 & 0.047 & - & 0.035 & - & 0.068 & 0.020 & 0.064 & 0.030 & 0.028 \\
\hline 3,5-dimethyl-3-heptanol & - & - & - & - & - & - & - & - & 0.043 & 0.051 \\
\hline 2,4-dimethyl-3-heptanol & - & - & - & - & - & - & - & - & - & 0.031 \\
\hline 3-methylthio-1-propranol & - & - & - & 0.019 & - & - & - & - & - & - \\
\hline
\end{tabular}


1-octen-3-ol

6-methyl-5-hepten-2-ol

4-cyclopentene-1,3-diol

2-ethyl-1-hexanol

phenylmethyl alcohol

3-methyl-1.5-pentanediol

5-nonanol

1-octanol

3,7-dimethyl-1,6-octadien-3-o

3,7-dimethyl-1,6-octadien-3-ol

2-nonanol

2-phenylethyl alcohol

trans-2-nonen-1-ol

cis-3-nonen-1-ol

1-nonanol

3,7-dimethyl-6-octen-1-ol (citronellol)

phenylpropyl alcohol

cis-4-decen-1-ol

9-decen-1-ol

1 -decanol

(Z)-5-decen-1-ol

(Z)-4-decen-1-ol

2-undecanol

undecanol

trans-2-undecen-1-ol

dodecanol

(Z)-2-dodecen-1-ol

3,7,11-trimethyl-1,6,10-dodecatrien-3-ol (nerolidol)

11-tridecen-1-ol

3,7,11-trimethyl-1-dodecanol (hexahydrofarnesol)

2-hexyl-1-octanol

(2Z)-1,3,3-trimethyl-2-(3-methyl-2-methylene-3-

butenilideno)cyclohexanol

1-tridecanol

$\alpha$-bisabolol

4-(2,6,6-trimethyl-1-cyclohexen-1-yl)-1-butanol

3,7,11-trimethyl-6,10-dodecadien-3-ol (dehydronerolidol)

(E)-2-tridecen-1-ol

3,7,11-trimethyl-2,6,10-dodecatrien-1-ol (farnesol)

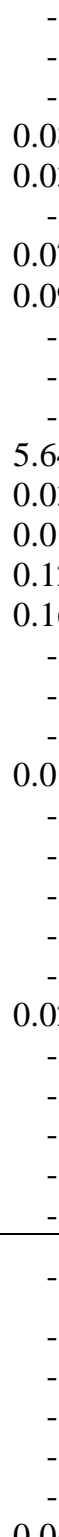

0.047

$\begin{array}{ccccc}- & - & - & - & 0.03 \\ - & - & - & - & \\ - & - & 0.032 & - & \\ .086 & 0.160 & - & 0.029 & \\ .037 & - & - & - & 0.08 \\ - & - & - & - & 0.05 \\ 0.076 & - & - & - & \\ 0.093 & 0.081 & - & 0.051 & 0.06 \\ - & - & - & - & \\ - & - & - & - & \\ - & 0.053 & - & 0.055 & 0.02 \\ 5.644 & 3.306 & 7.247 & 7.068 & 5.60 \\ 0.039 & 0.040 & - & - & \\ 0.019 & 0.084 & - & 0.016 & \\ 0.127 & 0.049 & - & 0.066 & \\ 0.164 & 0.103 & - & 0.089 & \\ - & - & - & - & 0.20 \\ - & - & - & - & \\ - & - & - & - & \\ .019 & 0.008 & - & - & \\ - & - & - & - & \\ - & - & - & - & \\ - & - & - & - & \\ - & - & - & - & \\ - & - & - & - & \\ 0.022 & 0.262 & - & 0.087 & - \\ - & - & - & - & \\ - & - & - & - & \\ - & 0.033 & - & - & \\ - & - & - & - & \\ - & - & - & - & -\end{array}$

0.023

0.019

0.007

0.082

0.050

0.063

0.039

0.046

.007

0.019

-

0.074

0.056
0.056

$\begin{array}{ll}0.027 & 0.059\end{array}$

$5.601 \quad 1.083$

0.045

0.048

0.206

0.130

0.078

0.078
0.069

0.747

0.028

0.170

0.114

0.203

-

-

0.043

0.034

-

0.024

0.127

0.069

0.088

$-$

$\begin{array}{lll}0.047 & 0.048 & 0.048\end{array}$

$\begin{array}{lll}1.012 & 0.752 & 1.278\end{array}$

$-$

0.254

-

0.039

$\begin{array}{lll}0.139 & 0.138 & 0.154\end{array}$

0.035

0.011

0.033

0.018

0.023

$-$

1.332

$-$

0.190

1.068

1.060

$\begin{array}{ll}- & 0.040\end{array}$

$-$

0.021

0.023

0.015

0.021

0.178

$-$

0.457

0.018

1.235

0.039

0.330

0.864

0.42

0.031

-

0.209

\begin{tabular}{lllll}
- & - & - & - & - \\
- & & - & - & 0.013 \\
\hline
\end{tabular}

0.028

0.577

0.132

0.351

0.091

$-$

0.580

0.013
0.102

0.058

1.165

0.012

0.099

0.045

0.023

$0.435-0.127$ 


\begin{tabular}{|c|c|c|c|c|c|c|c|c|c|c|}
\hline (6E)-3,7,11-trimethyl-6,10-dodecadien-1-ol (hydrofarnesol) & - & - & - & - & - & 0.642 & 0.326 & - & 0.263 & - \\
\hline (6E)-3,7,11-trimethyl-6,10-dodecadienol (dihydrofarnesol) & - & - & - & - & - & 0.072 & - & - & - & - \\
\hline 1,12-dodecanediol & - & - & - & - & - & - & - & - & - & 0.027 \\
\hline pentadecanol & - & - & - & - & - & - & 0.132 & - & 0.198 & - \\
\hline 9-hexadecyn-1-ol & - & - & - & - & - & - & 0.050 & - & - & - \\
\hline 14-methyl-8-hexadecyn-1-ol & - & 0.088 & - & - & - & - & - & - & - & - \\
\hline \multicolumn{11}{|l|}{ ALDEHYDE } \\
\hline Hexanal & - & - & 0.590 & - & - & - & - & - & - & - \\
\hline benzaldehyde & - & - & - & - & - & - & - & - & 0.015 & - \\
\hline Octanal & - & - & - & - & - & - & - & - & 0.032 & - \\
\hline 2-octenal & - & - & 0.015 & - & - & - & - & - & - & - \\
\hline benzeneacetaldehyde & 0.007 & & 0.013 & 0.007 & - & - & - & - & - & - \\
\hline Nonanal & 0.089 & 0.089 & 0.070 & 0.057 & 0.074 & 0.153 & 0.177 & 0.152 & 0.143 & 0.137 \\
\hline trans-2-nonenal & - & - & - & - & - & 0.034 & 0.043 & 0.032 & 0.023 & 0.026 \\
\hline Decanal & 0.054 & 0.075 & 0.034 & 0.089 & 0.084 & 0.112 & 0.113 & 0.089 & 0.110 & 0.110 \\
\hline 2,4-dimethylbenzaldehyde & 0.048 & 0.117 & - & 0.043 & 0.012 & - & - & - & - & - \\
\hline undecanal & - & - & - & - & - & - & - & 0.010 & - & 0.011 \\
\hline tetradecanal & - & - & - & - & - & 0.054 & - & - & 0.047 & - \\
\hline pentadecanal & - & - & - & - & - & 0.042 & 0.036 & 0.105 & 0.031 & 0.043 \\
\hline cis-9-hexadecenal & - & - & - & - & - & - & - & 0.027 & 0.059 & - \\
\hline 7,10,13-hexadecatrienal & 0.114 & - & - & - & - & - & - & - & - & - \\
\hline 7-tetradecenal & - & 0.093 & - & - & - & - & - & - & - & - \\
\hline \multicolumn{11}{|l|}{ ESTER } \\
\hline ethyl acetate & - & 0.413 & - & - & - & 0.329 & 0.166 & 0.045 & 0.096 & 0.208 \\
\hline propyl acetate & - & - & 0.730 & - & - & - & - & - & - & - \\
\hline isobutyl acetate & - & - & - & - & - & - & 0.127 & - & - & - \\
\hline ethyl lactate & - & 1.522 & - & - & - & - & 0.169 & - & - & - \\
\hline isoamyl acetate & 0.493 & 0.269 & 0.424 & 0.245 & 0.265 & 0.285 & 0.138 & 0.231 & 0.113 & 0.182 \\
\hline pentyl 2-propenoate & - & 0.056 & - & - & - & - & - & - & - & - \\
\hline ethyl hexanoate & 1.205 & 0.890 & 0.663 & 0.829 & 0.558 & 0.451 & 0.310 & 0.405 & 0.208 & 0.561 \\
\hline ethyl 2-hydroxy-4-methyl pentanoate & - & 0.118 & 0.025 & 0.077 & 0.141 & 0.058 & 0.062 & 0.023 & 0.028 & 0.084 \\
\hline isopentila 2-hydroxypropanoate & 0.041 & 0.060 & 0.030 & 0.023 & - & 0.027 & 0.039 & 0.010 & 0.020 & - \\
\hline ethyl heptanoate & 0.041 & 0.046 & 0.059 & - & 0.043 & - & - & 0.060 & - & 0.068 \\
\hline hexyl methoxyacetate & - & 0.088 & - & - & - & - & - & - & - & - \\
\hline 2-ethylhexyl acetate & - & 0.082 & - & - & - & - & - & - & - & - \\
\hline ethyl benzoate & - & - & - & - & 0.190 & - & - & 0.479 & - & 0.267 \\
\hline diethyl butanodiate & 1.322 & 1.728 & 0.559 & 1.091 & 0.536 & 0.169 & 0.139 & 0.065 & 0.185 & 0.110 \\
\hline methyl salicylate & & 0.023 & 0.115 & - & 0.164 & - & - & 0.094 & - & 0.208 \\
\hline ethyl octanoate & 12.631 & 15.635 & 12.318 & 13.371 & 7.791 & 9.150 & 12.210 & 10.552 & 10.602 & 6.344 \\
\hline
\end{tabular}


Research, Society and Development, v. 10, n. 4, e23410414009, 2021

(CC BY 4.0) | ISSN 2525-3409 | DOI: http://dx.doi.org/10.33448/rsd-v10i4.14009

octyl acetate

ethyl benzeneacetate

2-methylbutyl hexanoate

isopentyl hexanoate

phenylethyl acetate

ethyl 2-hydroxybenzoate

propyl octanoate

ethyl nonanoate

isobutyl octanoate

3,7-dimethyl-6-octen-1-yl acetate

vinyl decanoate

(4Z)-4-ethyl decenoate

ethyl 9-decenoate

ethyl decanoate

decyl acetate

ethyl cyclobutylsuccinate

isopentyl octanoate

metylbutyl 2-octanoate

ethyl 3-phenyl-2-propanoate

propyl decanoate

ethyl undecanoate

4-etil $t$-butilbenzoate

methyl isolaurate

methyl dodecanoate

isobutyl decanoate

ethyl dodecanoate

isoamyl nonanoate

isopentyl decanoate

methyl tridecanoate

ethyl tridecanoate

3,7,11-trimethyl-1,6,10-dodecatrien-3-yl acetate

nerolidyl acetate

methyl 2,4-dimethyl tetradecanoate

ethyl tetradecanoate

methyl Pentadecanoate

phenylethyl octanoate

ethyl pentadecanoate

HYDROCARBON

vinylbenzene

\subsection{1}

$-$

0.022

$-$

0.010

0.006

0.024

0.003

0.

0.082

0.082
1.256

0.032

0.010

- $\quad-$

0.004

.004

$-$

$\begin{array}{ccc}- & - & - \\ - & 0.005 & -\end{array}$

$\begin{array}{llcc}- & 0.005 & 0.001 & 0.003 \\ 0.410 & 1.057 & 0.262 & 0.608 \\ 0.042 & 0.028 & - & 0.027 \\ 0.007 & 0.006 & - & 0.007\end{array}$

$\begin{array}{llll}0.007 & 0.006 \quad- & 0.007\end{array}$

0.083

0.069

0.017

$\begin{array}{lll}- & - & -\end{array}$

$-$

$0.007-0.003$

-

0.002

0.004

-

$-$

$-$

-

0.005

0.051

0.011

-
-
0.025
-

0.009

0.013

0.016

0.012

$\begin{array}{lll}- & -004 \\ - & - & 0.053\end{array}$

0.053

0.051

0.031

0.072

0.011

0.017

0.339

0.339
8.188

0.053

0.011

0.443

0.104

$\begin{array}{ccc}- & - & - \\ - & - & 0.046\end{array}$

$0.003 \quad 0.005 \quad 0.046$

0.045

0.039

0.016

0.011

0.124

12.554

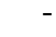

$-$

0.053

0.063

0.066

0.048

-

$-$

0.025

0.010

$-$

0.025

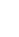

0.015

0.

$0.065 \quad 0.061$

$0.031 \quad 0.006$

- - -

$\begin{array}{lll}0.018 & 0.014 & 0.041\end{array}$

$\begin{array}{lll}0.424 & 0.167 & 0.105\end{array}$

$\begin{array}{lll}6.563 & 19.248 & 6.225\end{array}$

- - -

$\begin{array}{lll}0.081 & 0.431 & 0.053\end{array}$

$\begin{array}{lll}0.016 & 0.109 & 0.010\end{array}$

$\begin{array}{lcc}0.002 & - & -\end{array}$

$\begin{array}{lll}0.002 & - & - \\ 0.035 & 0.055 & 0.011 \\ 0.041 & 0.069 & 0.037\end{array}$

$\begin{array}{ccccc}- & - & - & - & - \\ - & - & - & - & 0.047\end{array}$

$\begin{array}{ccc}0.047 & - & - \\ 0.011 & - & 0.015 \\ 0.037 & 0.175 & 0.028\end{array}$

$\begin{array}{cccccc}- & - & - & 0.011 & - & 0.015 \\ - & 0.133 & 0.070 & 0.037 & 0.175 & 0.028 \\ 0.532 & 5.378 & 5.513 & 2.293 & 9.932 & 2.572\end{array}$

$\begin{array}{llllll}0.014 & 0.788 & 0.484 & 0.187 & 0.957 & 0.148\end{array}$

$\begin{array}{cccccc}0.014 & 0.788 & 0.484 & 0.187 & 0.957 & 0.148 \\ - & 0.191 & 0.116 & 0.051 & 0.244 & 0.040 \\ - & - & - & 0.034 & - & -\end{array}$

$-$

$\begin{array}{ll}- & 0.034 \\ 0.534 & 0.285\end{array}$

$-$

$0.606 \quad 0.220$

$\begin{array}{ll}.030 & 0.956 \\ - & 0.762\end{array}$

0.534

0.285

0.371

0.025

0.130

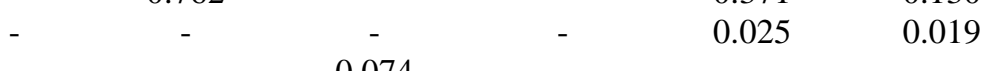

$\begin{array}{cccccc}- & - & 0.074 & - & - & - \\ .013 & 0.206 & 0.081 & 0.157 & 0.075 & 0.136\end{array}$

$\begin{array}{llllll}0.013 & 0.206 & 0.081 & 0.157 & 0.075 & 0.136 \\ 0.008 & - & - & 0.021 & 0.118 & 0.010\end{array}$

$\begin{array}{rr}0.118 & 0.010\end{array}$

$\begin{array}{lllll}- & - & - & - & 0.058 \\ 011 & 0.117 & 0.061 & 0.171 & 0.062\end{array}$

0.062

0.021 
1-isopropyl 3-methylcyclohexene (m-menthane)

1-methyl-3-isopropylbenzene ( $m$-cymene)

3-isopropyl-6-methylene-1-cyclohexene (2-p-menthene)

(S)-1-methyl-4-(1-metil ethenyl)-cyclohexene (limonene)

1,2-dimethyl-4-vinylbenzene

2-methoxyphenol (guaiacol)

1,2,4,5-tetramethylbenzene

1-isopropenyl-4-methyl-1,3-cyclohexadiene ( $p$-mentha-

1,3,8-triene)

1,2,3,4-tetramethylbenzene

1-methoxy-4-vinylbenzene (4-vinylanisole)

4-ethylphenol

naphthalene

nonylcyclopropane

4-ethyl-2-methoxyphenol (4-ethylguaiacol)

1,1,6-trimethyl-1,2,3,4-tetrahydronaphthalene (ionene)

2-methoxy-4-vinylphenol (4-vinylguaiacol)

1-tridecyne

1,1,4,7-tetramethylindane

1,1,6-trimethyl-1,2-dihydronaphthalene (3,4-dehydroionene)

4-propyl-2-methoxyphenol (4-propylguaiacol)

1,2-dimethoxy-4-vinylbenzene (4-vinylveratrole)

2-(1,3-butadienyl)-1,3,5-trimethylbenzene (1-mesitylbuta-

1.3-diene)

2-isopropyl-6-tert-butylphenol

1-isopropenyl-2,3,4,6-tetramethylbenzene

1-isopropenyl-2,3,4,5-tetramethylbenzene

4-isopropyl-1,6-dimethyl-1,2,3,4,4a,7- hexahidro

naphthalene (cadinadiene-1.4)

7-tetradecyne

1,1,5,6-tetramethylindane

2-(2-butenyl)-1,3,5-trimethyl benzene

(E)-7,11-dimethyl-3-methylene-1,6,10-dodecatriene

2-[(1E)-1,3-butadienyl]-1,3,5-trimethylbenzene

1,5,8-trimethyl-1,2-dihydronaphthalene

2,6-di-tert-butyl-4-methoxymethylphenol (ionol 4)

cadala-1(10).3,8-triene

1-ciclohexilnoneno

2,6,10-trimethyltetradecane
0.017

0.051
- 049

0.053
0.047
0.013

0.013

$-$

$\begin{array}{lll}- & - & - \\ - & - & -\end{array}$


Research, Society and Development, v. 10, n. 4, e23410414009, 2021

(CC BY 4.0) | ISSN 2525-3409 | DOI: http://dx.doi.org/10.33448/rsd-v10i4.14009

\begin{tabular}{|c|c|c|c|c|c|c|c|c|c|c|}
\hline (cyclohexylmethyl)-2-ethyl cyclohexane & - & - & - & 0.029 & - & - & - & - & 0.038 & - \\
\hline 1-(cyclohexylmethyl)-4-isopropylcyclohexane & - & 0.041 & 0.057 & - & - & 0.027 & 0.051 & - & - & - \\
\hline 5-phenylundecane & - & - & - & - & - & - & - & 0.027 & - & - \\
\hline 1-heptadecyne & - & - & - & - & - & - & - & - & - & 0.023 \\
\hline (4-pentylcyclohexyl)benzene & - & - & - & - & - & - & - & - & 0.026 & - \\
\hline \multicolumn{11}{|l|}{ KETONE } \\
\hline acetophenone & - & - & 0.076 & - & - & 0.057 & 0.067 & 0.078 & 0.075 & 0.057 \\
\hline 2-nonanone & - & - & - & - & - & 0.027 & 0.038 & 0.019 & - & 0.035 \\
\hline 5-isopropenyl-2-methylcyclohexanone (dihydrocarvone) & - & - & - & - & - & - & - & - & 0.045 & - \\
\hline 5-isopropyl-2-methylcyclohexanone ( $p$-menthan-2-one) & - & - & - & - & - & 0.047 & 0.038 & - & 0.071 & - \\
\hline trans-2-methyl-5-(1-methyl-1-ethyl)-cyclohexanone & - & - & - & - & - & - & - & 0.038 & - & 0.057 \\
\hline 2-undecanone & - & - & - & - & - & - & 0.057 & 0.067 & 0.078 & 0.075 \\
\hline $\begin{array}{l}\text { (2E)-1-(2,6,6-trimethyl-1,3-cyclohexadien-1-yl)-2-buten-1- } \\
\text { one ( } \beta \text {-damascenone) }\end{array}$ & - & - & - & - & - & 0.037 & 0.067 & 0.018 & 0.045 & 0.051 \\
\hline 2-tetradecanone & - & 0.051 & - & - & - & 0.035 & 0.041 & - & - & - \\
\hline $\begin{array}{l}\text { 1-(6,6-dimethyl-1.2-epoxy cyclohexyl)-1-buten-3-one } \\
\text { ( } \beta \text {-ionone epoxide) }\end{array}$ & - & - & - & - & - & 0.023 & - & - & - & - \\
\hline $\begin{array}{l}\text { 4-(2,2,6-trimethyl-5-cyclohexen-1-yl)-2-butanone (dihydro- } \\
\alpha \text {-ionone) }\end{array}$ & - & - & - & - & - & - & - & 0.062 & - & - \\
\hline (5Z)-6.10-dimethyl-5.9-undecadien-2-one & 0.057 & 0.057 & - & 0.048 & 0.063 & - & 0.057 & 0.067 & 0.078 & 0.075 \\
\hline 2-tridecanone & - & - & - & - & - & - & - & 0.017 & - & - \\
\hline $\begin{array}{l}\text { 1-(2,6,6-trimethyl-1-cyclohexen-1-yl)-1-penten-3-one ( } \beta \text { - } \\
\text { methyl ionone) }\end{array}$ & - & - & - & - & - & - & - & 0.050 & - & 0.047 \\
\hline \multicolumn{11}{|l|}{ OTHERS (mixed function) } \\
\hline (3-methyl-oxiran-2-yl)-methanol & - & - & - & - & 0.019 & - & - & - & - & - \\
\hline 3-(methylsulfanyl)-1-propanol & 0.057 & - & - & - & - & - & - & - & - & - \\
\hline 2-propyltetrahydropyran & - & - & - & - & 0.028 & - & 0.026 & 0.029 & - & - \\
\hline 5-methyltetrahydro-2-furanylmetanol & - & - & - & - & - & 0.044 & - & - & 0.039 & 0.057 \\
\hline 5-(hydroxymethyl)tetrahydro-2-furan & - & - & - & - & - & - & - & - & - & 0.047 \\
\hline 2,3-dihydro-benzofuran & 0.038 & - & 0.026 & 0.029 & 0.026 & - & - & 0.046 & - & - \\
\hline 1-(2-hydroxy-5-methylphenyl)ethanone & - & 0.077 & - & - & - & - & - & - & - & - \\
\hline
\end{tabular}

Source: Authors. 
The must samples grouped into two groups, one formed by samples SS3 and SF2, and other by samples SS1, SS2 and SF1. Cachaça samples formed three groups: one composed by the beverages produced by the strains SS3 and SF2, the second constituted by the cachaças SS1 and SS2, and the third was represented by the cachaças obtained from the spontaneous fermentation SF1. The analysis of HCA data (Figure 2) revealed the presence of five groups of composition identical to the PCA grouping, and minimum similarity of $71.98 \%$.

Figure 2. Representative dendrogram of the volatile compounds identified in the must and cachaça samples studied.

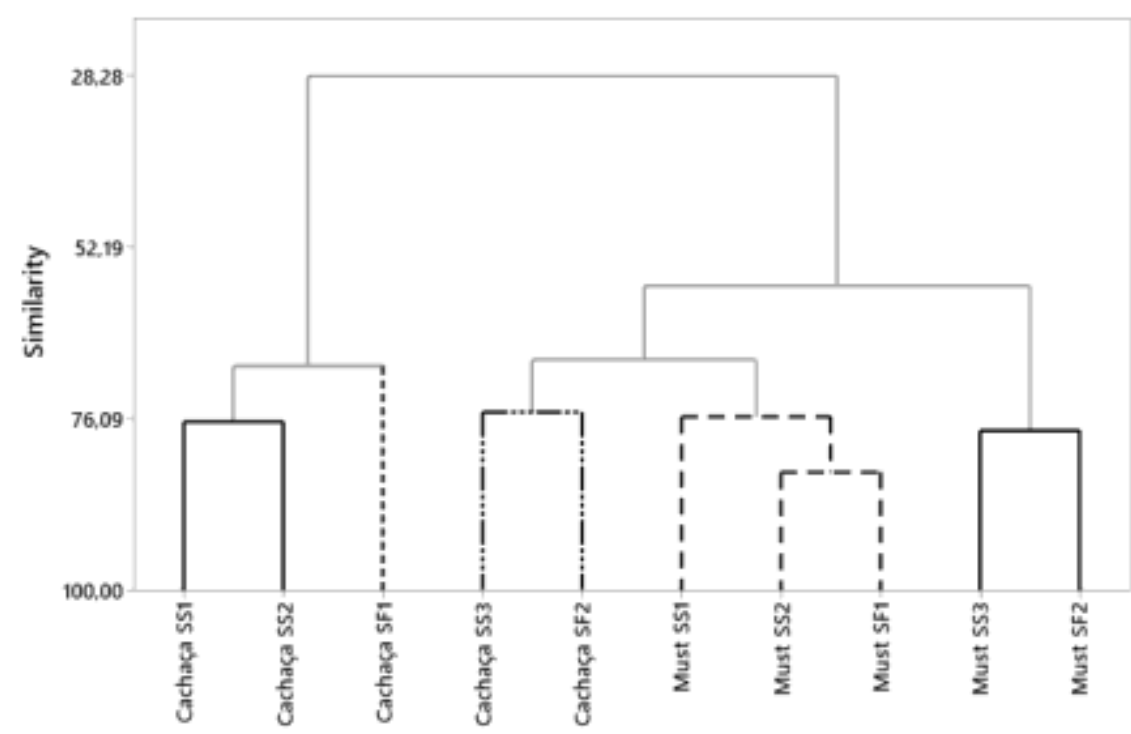

Source: Authors.

According to the Loading Plot (Figure 3), the grouping of must samples SS3 and SF2 was determined by the higher concentrations of ethanol and by the presence of acetic acid, which was exclusively detected in these samples. 
Figure 3. PCA loading plot of the volatile compounds obtained from the must and cachaça samples.

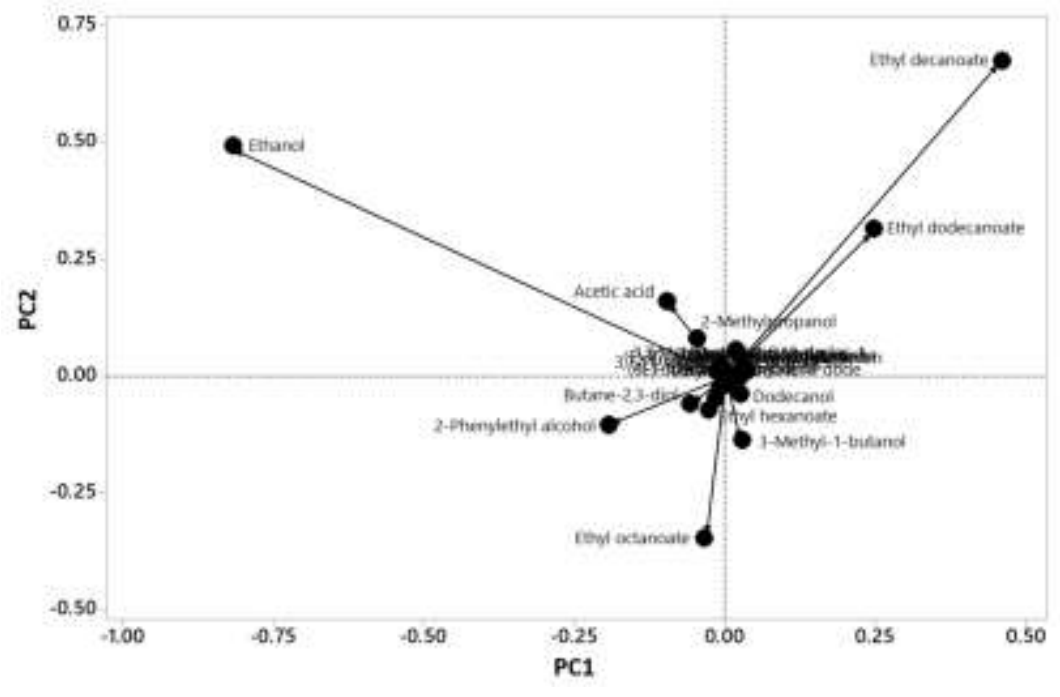

Fonte: Autores.

These were the only samples in which octanoic acid was detected. The must group formed by SS1, SS2 and SF1 samples had lower alcohol and 2-methylpropanol concentrations. Higher concentrations of butane-2,3-diol and diethyl butanedioate also contributed to this grouping. The group formed by cachaças SS3 and SF2 was mainly influenced by the higher values of ethanol and by similar values for ethyl decanoate and ethyl dodecanoate. The similarity in the concentrations of ethyl dodecanoate determined the grouping of cachaças SS1 and SS2. The last group, exclusively represented by cachaças obtained from spontaneous fermentation SF1, was mainly formed because of the higher relative areas of ethyl decanoate and ethyl dodecanoate. Moreover, SF1 samples were the only ones containing 1,1-diethoxy-2-methylbutane, (Z)-4-decen-1-ol, undecanol, benzaldehyde, octanal, phenylethyl octanoate, 2-isopropyl-6-tert-butylphenol, 2-[(1E)-3-butadienyl]-1,3,5trimethylbenzene, cadala-1(10)-3,8-triene, 4-(pentylcyclohexyl)benzene and dihydrocarvone.

\section{Discussion}

In this study, the profile of organic volatile compounds was determined in musts and cachaças produced using selected S. cerevisiae yeast strains. Because spontaneous fermentation is the method of choice for the production of alembic cachaça, it was used for comparison with beverages produced using selected strains. Although must is not the commercialized fraction, analyses of such samples furnishes information regarding the chemical compounds that are produced during the fermentation step. Furthermore, to the best of our knowledge, no study has been conducted to determine the chemical composition of the volatile fraction of musts.

Predominant alcohols, esters, ketones and acetals detected in the samples have been described in the literature as contributors to the quality of alcoholic beverages (Voss et al., 2019). Amorim et al. (2016) found the same alcohols identified in the present study - 3-methylbutanol, 2-phenylethyl alcohol and 2-methylpropanol — prevalent in cachaça samples. According to Duarte et al., (2013), the relative content of 2-phenylethanol can be affected by the dominant type of yeast during fermentation, as well as by the fractionation process during distillation. This alcohol is considered one of the most significant higher alcohols in beverages aroma because of its floral nuances (De Souza et al., 2006).

The number of esters detected in our samples was similar to that found in alcohols. Esters are produced during fermentation by yeasts, and are responsible for assigning positive sensory characteristics to alcoholic beverages (Gonçalves et at., 2016). Ethyl decanoate, described in the literature as grape aroma, was previously identified in Brazilian cachaças using 
SPME (De Souza et al., 2009) and gas chromatography (Serafim \& Franco, 2015), and ethyl acetate was reported as the predominant ester in cachaças (Serafim \& Franco, 2015).

Aldehydes are intermediates in the formation of alcohols originated by the decarboxylation of oxyacids, they are also obtained by oxidation reaction or by partial degradation of amino acids present in sugarcane broth. Some aldehydes are considered toxic to humans, and those with pungent flavours can negatively affect the sensory quality of sugarcane spirits (Cardoso, 2020). De Souza et al. (2009) studied volatile compounds in Brazilian cachaça by using comprehensive twodimensional gas chromatography ( $\mathrm{GC} \times \mathrm{GC})$. The authors found some aldehydes, including nonanal, decanal and pentadecanal, that were also found in our work in all the cachaca samples analyzed.

The small number of ketones detected in musts was expected because, according to Prado-Jaramilo et al. (2015), these compounds are produced after distillation. $\beta$-Damascenone is a ketone of great importance in the study of volatile compounds, which is present in many products derived from vegetables, and has a perception limit of $2 \mathrm{ng} \mathrm{L}^{-1}$ in water. The presence of ketones in cachaças can be considered a positive characteristic, since they have been identified as the most potent floral-fruity odorants in unaged cachaça (De Souza et al., 2006). $\beta$-Damascenone was found in all the cachaça samples evaluated. The origin of this compound can be associated with secondary fermentation processes, or can be derived from the raw material as, for example, the damascenone (exotic flower or rose) (Serafim \& Lanças, 2019).

Carboxylic acids are produced by yeasts or bacterial contaminants and have a strong influence on the sensorial features of the beverages, as well as on the stability of the musts. High acidity in cachaça can be associated with inadequate control of fermentation, which facilitates the entry of acetic bacteria. Large amounts of acid in cachaça can cause a decrease in ethanol content, and represents the most common and important defect of the beverage (Badotti et al., 2012). A balanced acidity in cachaça is a desirable characteristic. The use of selected yeasts is a good strategy for achieving greater control over the production process. Hexanoic, octanoic and decanoic acids, found in the present work, have already been detected in alembic cachaça samples (Duarte e al., 2013).

Acetals often appear in small quantities in alcoholic beverages, and they usually give a refreshing odour to cachaça, either by reducing the pungent odour of acetaldehyde or by reinforcing fruity aromas. Acetals arise during fermentation as the result of the combination of an alcohol molecule with an aldehyde to producing an unstable semiacetal, which then combines with another alcohol molecule to create a stable acetal that does not decompose even during the distillation process (Santiago et al., 2016). The acetals 1,1-diethoxy-3-methylbutane, 1,1-diethoxy-2-methylbutane and 1,1-diethoxyhexane were identified in the present work, as well as in the study of cachaças and cognac (Cardeal et al., 2008; Thibaud; Shinkaruk \& Darriet, 2019) The compositions of musts and cachaças are complex and variable, which made the interpretation of the data based on visual analyses inappropriate. Multivariate analysis was used to examine the correlation between the chemical composition of samples and the different fermentative systems tested here (spontaneous and selected strains).

The differences found in the chemical compositions of must and cachaça were not surprising (Table 1) because several chemical reactions induced by heat take place inside the distiller during distillation, leading to the formation of new compounds and the disappearance of others. Besides distillation, musts and cachaças also seem to be influenced by the distillery environment. Musts and cachaças produced in the distillery A (SS1, SS2, and SF1) were more similar than those produced in distillery B (SS3 and SF2), and formed two separate groups (Fig. 1). Although the influence of the distillery environment was not the focus of this study, it is widely known that the microbiota colonizing plants and surfaces of the facilities participate in the fermentative process (Badotti et al., 2012), and they can directly influence the chemical composition of musts and cachaças. 


\section{Conclusion}

Our data revealed that the use of yeast strains isolated from spontaneous fermentations (autóctones strains) as starters results in cachaças with chemical compositions similar to those produced by spontaneous fermentations. This is a good result because one of the main concerns of cachaça producers regarding the use of starter strains is the loss of product identity. We demonstrated that the use of yeast strains isolated from the cachaça-producing microenvironment as starters preserves the identity of this traditional Brazilian product at the same time that improves its quality and productivity.

Most of the volatile chemical compounds detected in the cachaças produced by the three S. cerevisiae strains (SS1, SS2, and SS3) can contribute to the quality of the beverages, so we consider these strains are promising candidates for largescale alembic cachaça production. None of the contaminants mentioned by the Brazilian Legislation - ethyl carbamate or the alcohols methanol, 1-butanol, and 2-butanol - were detected in our samples, this may be due to the technique of sampling of volatile compounds in the head space. The cachaças produced also had a low acid content, which is considered an important quality attribute. Our results indicate that the use of selected autóctones strains, such as SS1, SS2, and SS3, is a promising alternative for the production of safe and high-quality cachaças. Finally, we identified the chemical composition of musts produced by spontaneous and selected strains for the first time, which might help in understanding the complex chemical reactions that occur throughout the fermentation and distillation processes of cachaça production.

\section{Acknowledgments}

We are grateful to professors David Lee Nelson and Demetra N. Skaltsas for correcting the English grammar.

\section{References}

Adams, R. P. (2007). Identification of essential oil components by gas chromatography/mass spectroscopy, (4th ed.), Allured Publishing Corporation, Carol Stream.

Amorim, J. C., Schwan, R. F. \& Duarte, W. F. (2016). Sugar cane spirit (cachaça): Effects of mixed inoculum of yeasts on the sensory and chemical characteristics. Food Research International. 85, 76-83. 10.1016/j.foodres.2016.04.014.

Badotti, F., Belloch, C., Rosa, C. A., Barrio, E. \& Querol, A. (2010). Physiological and molecular characterisation of Saccharomyces cerevisiae cachaça strains isolated from different geographic regions in Brazil. World Journal of Microbiology and Biotechnology, 26(4), 579-587. 10.1007/s11274-009-0206-0.

Badotti, F., Gomes, F. C. O. \& Rosa, C. (2012). Brazilian Cachaça: Fermentation and Production. In Hui, Y. H. \& Özgül Evranuz, E. (eds), Handbook of Plant Based Fermented Foods and Beverages (pp. 639-648). CRC Press: Florida, USA.

Barbosa, E. A., Souza, M. T., Diniz, R. H. S., Godoy-Santos, F., Faria-Oliveira, F., Correa, L. F. M. \& Brandão, L. R. (2016). Quality improvement and geographical indication of cachaça (Brazilian spirit) by using locally selected yeast strains. Journal of Applied Microbiology, 121, 1038-1051. doi:10.1111/jam.13216.

Borges, G. B. V., Gomes, F. C. O., Badotti, F., Silva, A. L. D. \& Machado, A. M. R. (2014). Selected Saccharomyces cerevisiae yeast strains and accurate separation of distillate fractions reduce the ethyl carbamate levels in alembic cachaças. Food Control, 37, 380-384. 10.1016/j.foodcont.2013.09.013.

Bortoletto, A. M. \& Alcarde, A. R. (2015). Assessment of chemical quality of Brazilian sugar cane spirits and cachaças. Food Control, 54, 1-6. 10.1016/j.foodcont.2015.01.030.

Cardeal, Z. L., De Souza, P. P., Gomes da Silva, M. D. R. \& Marriott, P. J. (2008). Comprehensive two-dimensional gas chromatography for fingerprint pattern recognition in cachaça production. Talanta, 74, 793-799. doi:10.1016/j.talanta.2007.07.021.

Cardoso, M. G. (2020). Compostos Secundários da Cachaça. In: Cardoso, M. G. Produção de aguardente de cana. (4th ed.), UFLA, 445p.

Charry-Parra, G., De Jesus-Echevarria, M. \& Perez, F. J. (2011). Beer Volatile Analysis: Optimization of HS/SPME Coupled to GC/MS/FID. Journal of Food Science, 76, C205-211. 10.1111/j.1750-3841.2010.01979.x.

De Souza, M. D. C. A., Vásquez, P., Del Mastro, N. L., Acree, T. E. \& Lavin, E. H. (2006). Characterization of Cachaça and Rum Aroma. Journal of Agricultural and Food Chemistry. 54(2), 485-488. 10.1021/jf0511190.

De Souza, P. P., Cardeal, Z. L., Augusti, R., Morrison, P. \& Marriot, P. J. (2009). Determination of volatile compounds in Brazilian distilled cachaça a by using comprehensive two-dimensional gas chromatography and effects of production pathways. Journal of Chromatography A, 121, 62881-2890. 10.1016/j.chroma.2008.10.061. 
D’Silva, A. F., Badotti, F., Pinheiro, C. S. R., Gonçalves, C. M., Hughes, F. M., Rosa, C. A., Góes Neto, A. \& Uetanabaro, A. P. T. (2019). Diversity of Saccharomyces cerevisiae strains isolated of the spontaneous fermentation of cachaça from northeastern Brazil. Brazilian Journal of Development, 5(11), 27448-27461. 10.34117/bjdv5n11-348.

Duarte, W. F., Amorim, J. C. \& Schwan, R. F. (2013). The effects of co-culturing non-Saccharomyces yeasts with S. cerevisiae on the sugar cane spirit (cachaca) fermentation process. Antonie van Leeuwenhoek, 103, 175-194. 10.1007/s10482-012-9798-8.

Faria-Oliveira, F., Diniz, R. H. S., Godoy-Santos, F., Piló, F. B., Mezadri, H., Castro, I. M. \& Brandão, R. L. (2015). The role of yeast and lactic acid bacteria in the production of fermented beverages in South America. In Eissa, A. H. A. (ed), Food Production and Industry (pp.107-135). INTECH Open Access Publisher: Rijeka, Croácia.

Gonçalves, R. C. F., Teodoro, M. M. G., Machado, A. M. R., Gomes, F. C. O., Badotti, F. \& Cardoso, M. G. (2016). Compostos voláteis em cachaças de alambique produzidas por leveduras selecionadas e por fermentação espontânea. Magistra, 28(3/4), $285-293$.

Gomes, F. C. O., Silva, C. L.C., Marini, M. M., Oliveira, E.S. \& Rosa, C. A. (2007). Use of selected indigenous Saccharomyces cerevisiae strains for the production of the traditional cachaça in Brazil. Journal of Applied Microbiology, 103, 2438-2447. 10.1111/j.1365-2672.2007.03486.x.

Khio, S. W., Cheong, M. W., Zhou, W. B., Curran, P. \& Yu, B. (2012). Characterization of the Volatility of Flavor Compounds in Alcoholic Beverages through Headspace Solid-Phase Microextration (HS-SPME) and Mathematical Modeling. Journal of Food Science. 77(1), C61-C70. 10.1111/j.17503841.2011.02474.x.

MINITAB INC. (2017) Minitab statistical software. Version 18.1 for Windows. State College, Pennsylvania: Minitab Inc.

Paredes, R. S., Vieira, I. P. V., de Mello, V. M., Vilela, L. F., Schwan, R. F. \& Eleutherio, E. C. A. (2018). Identification of three robust and efficient Saccharomyces cerevisiae strains isolated from Brazilian's cachaça distilleries. Biotechnology Research and Innovation, 2(1), 22-29. 10.1016/j.biori.2018.07.001.

Pérez-González, M., Gallardo-Chacón, J. J., Valencia-Flores, D. \& Ferragut, V. (2015). Optimization of a Headspace SPME GC-MS Methodology for the Analysis of Processed Almond Beverages. Food Analytical Methods. 8(3), 612-623. 10.1007/s12161-014-9935-2.

Portugal, C. B., Alcarde, A. R., Bortoletto, A. M. \& de Silva, A. P. (2016). The role of spontaneous fermentation for the production of cachaça: a study of case. European Food Research and Technology, 242(9), 1587-1597. 10.1007/s00217-016-2659-3.

Prado-Jaramilo, N., Estarrón-Espinosa, M., Escalona-Buendía, H., Cosío-Ramirez, R. \& Martin-del-Campo, S. T. (2015). Volatile compounds generation during different stages of the Tequila production process. A preliminary study. LWT - Food Science and Technology. 61(2), 471-483. 10.1016/j.lwt.2014.11.042.

Ruiz-Delgado, A. F. J., Romero-Gonzalez, R., López-Ruiz, R. \& Frenich, A. G. (2016). Headspace solid-phase microextraction coupled to gas chromatography-tandem mass spectrometry for the determination of haloanisoles in sparkling (cava and cider) and non-sparkling (wine) alcoholic beverages. Food Additives \& Contaminants Part A. 33(10), 1535-1544. 10.1080/19440049.2016.1229870.

Santiago, W. D., Cardoso, M. G., Santiago, J. A., Teixeira, M. L., Barbosa, R. B., Zacaroni, L. M. \& Nelson, D. L. (2016). Physicochemical profile and determination of volatile compounds in cachaça stored in new oak (Quercus sp.), amburana (Amburana cearensis), jatoba (Hymenaeae carbouril), balsam (Myroxylon peruiferum) and peroba (Paratecoma peroba) casks by SPME-GC-MS. Journal of the Institute of Brewing. 122, 624-634. 10.1002/jib.372.

Serafim, F. A. T. \& Franco, D. W. (2015). Chemical traceability of industrial and natural yeasts used in the production of Brazilian sugarcane spirits. Journal of Food Composition and Analysis, 38, 98-105. 10.1016/j.jfca.2014.11.001.

Serafim, F. A. T. \& Lanças, F. M. (2019). Sugarcane Spirits (Cachaça) Quality Assurance and Traceability: an Analytical Perspective. In Grumezescu, A. M. \& Holban, A. M. (eds), Production and Management of beverages: The Science of Beverages (pp. 335-359). Elsevier: Amsterdã, Holanda. 10.1016/B978-0-12815260-7.00011-0.

Silva, E. A. S. \& Pawliszyn, J. (2012). Optimization of Fiber Coating Structure Enables Direct Immersion Solid Phase Microextraction and High-Throughput Determination of Complex Samples. Analytical Chemistry, 84(16), 6933-6938. 10.1021/ac301305u.

Thibaud, F., Shinkaruk, S. \& Darriet, P. (2019). Quantitation, Organoleptic Contribution, and Potencial Origin of Diethyl Acetals Formed from Various Aldehydes in Cognac. Journal of Agricultural and Food Chemistry, 67(9), 2617-2625. 10.1021/acs.jafc.9b01084

Voss, H. G. J, Mendes Júnior, J. J. A., Farinelli, M. E. \& Stevan Jr, S. L. (2019). A Prototype to Detect the Alcohol Content of Beers Based on an Electronic Nose. Sensors. 19, 2646-2659. 10.3390/s19112646. 